\title{
Energy-cane: resistant to major sugarcane diseases?
}

\author{
Caña para energía: ¿Resistente a las principales enfermedades de la caña de azúcar? \\ Antônio R. F. Junior ${ }^{1}$; Amaro A. C. de Azeredo ${ }^{1}$; Tales Romano ${ }^{1 *}$; Bruno P. Brasileiro ${ }^{1}$; \\ João C. Bespalhok Filho ${ }^{1}$; Lucimeris Ruaro ${ }^{1}$; Edelclaiton Daros ${ }^{1}$ and Ricardo A. de Oliveira ${ }^{1}$
}

\begin{abstract}
This study's objectives were to compare the occurrence of brown rust and smut in conventional and energy cane families and clones in field conditions and to understand how the new hybridizations could contribute to increasing the allele frequency of resistance against the main crop diseases in breeding populations. Disease occurrence was evaluated in two selection stages. Of the 2.400 clones constituting the material for selection in the first stage, 88 clones $(\approx 4 \%$ of the total) were selected for the second stage. Considering the overall performance of the clones without symptoms of either disease in the evaluated families that would be possibly selected in the second stage, the percentage was at least $28 \%$ lower in the families selected for high biomass (37.33\%) than of the selected conventional (57.14\%) and intermediate biomass (66.67\%) families. In the intermediate biomass and high biomass sugarcane families, brown rust and smut rates were higher in the first stage. In the second stage, brown rust incidence was higher in high biomass families. However, at the end of both selection phases, intermediate biomass and high biomass sugarcane clones without simultaneous brown rust and smut symptoms could be selected.
\end{abstract}

Keywords: Saccharum spp, Puccinia melanocephala, Sporisorium scitamineum, biomass, plant breeding.

\section{RESUMEN}

El objetivo de este estudio fue comparar la incidencia de roya marrón y carbón en familias y clones de caña de azúcar convencional y caña de azúcar para energía, a fin de evaluar el efecto de las hibridaciones en la frecuencia alélica de resistencia a estas enfermedades en el mejoramiento de los cultivos. La ocurrencia de las enfermedades fue observada en dos etapas de selección. En la primera etapa se evaluaron 30 familias, clasificadas según tipo de familia: cinco familias de caña de azúcar convencional (CO); trece familias de caña de azúcar para producción de energía con alta biomasa $(H B)$ y, doce familias de caña de azúcar para producción de energía con biomasa intermedia (IB). Durante la segunda etapa, se evaluaron 88 genotipos libres de enfermedad: siete genotipos CO; 60 genotipos HB y 21 genotipos IB. En la primera fase de selección se observaron tasas más altas de carbón y roya en familias de caña de azúcar de biomasa intermedia (IB) y alta (HB). En la segunda fase de selección, la incidencia de la roya de las familias de alta biomasa (HB) fue mayor. En las familias con biomasa media y alta las tasas de roya marrón y carbón resultaron mayores en el primer estadio. En el segundo estadio, la incidencia de roya marrón fue mayor en las familias con alta biomasa. Al final de dos fases, se seleccionaron clones de caña de azúcar de biomasa intermedia y alta, sin síntomas de ninguna de las enfermedades evaluadas.

Palabras clave: Saccharum spp, Puccinia melanocephala, Sporisorium scitamineum, biomasa, mejoramiento genético.

\section{Introduction}

The possibility of profitable use of biomass for power cogeneration and cellulosic ethanol production of has inspired new sugarcane research lines, mainly to increasing fiber content and stalk yield of future varieties (Ramos et al., 2017). To raise the fiber content in future varieties, researchers proposed the exploitation of Saccharum spontaneum and $S$. robustum accessions crossed with highperforming commercial hybrids (S. spp.), intending to breed energy cane varieties (Ramos et al. 2017). These species' accessions should also be used to increase the frequency of resistance genes to the major crop diseases (Matsuoka et al. 2014).

Brown rust (Puccinia melanocephala) is one of the main sugarcane diseases. This fungal parasite attacks leaf tissues, where it produces the typical rust symptoms, prominent pustules, which are easily diagnosed in the field (Tokeshi and Rago 2005). For Brazil's field conditions, a productivity reduction of up to $47 \%$ was reported,

\footnotetext{
1 Universidade Federal do Paraná (UFPR), Departamento de Fitotecnia e Fitossanitarismo, Curitiba - Paraná, Brasil.

* Corresponding author: talesrom@gmail.com; Orcid ID: 0000-0003-0724-2400.
}

Fecha de Recepción: 19 de Mayo, 2020.

Fecha de Aceptación: 13 de Julio, 2020. 
and for the most susceptible varieties, the damage level can exceed 60\% (Matsuoka 1993). Resistant plant breeding is the only economic measure of brown rust control (Tokeshi and Rago 2005). The heritability of disease resistance is high, indicating that the elimination of susceptible parents is a good strategy for developing resistant varieties (Ramdoyal et al. 2000).

Another important sugarcane disease is smut (Sporisorium scitamineum). Caused by a fungal parasite that attacks plant's the meristematic tissues, it produces a structure known as "whip," a typical symptom o infected stalks. This structure is an alteration of the stem morphology and consists of plant tissue tapered and covered with a black mass of the fungus teliospores. The "whip" is easily identified in the field and allows a safe diagnosis of the disease (Tokeshi and Rago 2005).

Smut is considered a major concern in all breeding programs, causing breeders to choose resistant parents (Rago et al., 2009). Damage levels of $50 \%$ to $73 \%$ lower in ratoon crop yields caused by the disease were reported (Bergamin Filho et al. 1987, Ido et al., 2006). In view of the need to develop new sugarcane biotypes, using hybridizations of $S$. spontaneum and $S$. robustum accessions, the objective of this study was to compare the occurrence of brown rust and smut in conventional and energy cane families and clones under natural field conditions, to understand how these new hybridizations can contribute to increasing the allele frequency of resistance to the major sugarcane diseases in breeding populations.

\section{Material and methods}

\section{First selection phase (T1)}

The crosses were made in 2012, at the Station of Serra do Ouro for flowering and crosses, of the Federal University of Alagoas (UFAL), in Murici, Alagoas, Brazil (latitude $9^{\circ} 13$ 'S , longitude $35^{\circ} 50$ 'W; $450 \mathrm{~m}$ asl) and at the Station of Devaneio for flowering and crosses, of the Federal Rural University of Pernambuco (UFRPE), in Amaraji, Pernambuco, Brazil (latitude $8^{\circ} 19,8^{\prime}$ S, longitude $35^{\circ} 24,8$ 'W; $514 \mathrm{~m}$ asl). The caryopses derived from the crosses were prepared and sent to the Experimental Station Paranavaí, of the Federal University of Paraná (UFPR), in Paranavaí, Paraná (latitude $23^{\circ} 05^{\prime} \mathrm{S}$, longitude $52^{\circ} 27^{\prime} \mathrm{W}$; $503 \mathrm{~m}$ asl).

Seeds were sown, and seedlings were produced to plant the first selection phase of the experiment (T1) in February 2013. In this phase, 30 families were evaluated (Table 1) in a randomized complete block design. Each plot consisted of 20 seedlings,

Table 1. Parents of 30 evaluated families and classification of the crosses according sugarcane ideotype.

\begin{tabular}{|c|c|c|c|c|c|}
\hline \multicolumn{3}{|c|}{ Families* } & \multicolumn{3}{|c|}{ Families* } \\
\hline Mother & Father & Ideotype & Mother & Father & Ideotype \\
\hline RB855156(1) & RB987935(1) & $\mathrm{CO}$ & Co62175(1) & $28 \mathrm{NG} 289^{(3)}$ & $\mathrm{HB}$ \\
\hline RB867515(1) & RB965518(1) & $\mathrm{CO}$ & RB93509(1) & $\mathrm{Co} 285^{(4)}$ & $\mathrm{HB}$ \\
\hline RB867515(1) & RB996961(1) & $\mathrm{CO}$ & SP81-3250(1) & US85-1008(4) & $\mathrm{HB}$ \\
\hline RB966928(1) & TUC77-42(1) & $\mathrm{CO}$ & $\operatorname{Co} 421^{(5)}$ & POJ2878(6) & IB \\
\hline SP80-3280(1) & RB867515(1) & $\mathrm{CO}$ & $\operatorname{Co} 421^{(5)}$ & RB93509(1) & IB \\
\hline $\mathrm{F} 150^{(6)}$ & IN84-88(2) & $\mathrm{HB}$ & $\operatorname{CoS} 245^{(6)}$ & RB813804(1) & IB \\
\hline IAC $87-3396^{(1)}$ & US85-1008(4) & $\mathrm{HB}$ & Co617(5) & POJ2878(6) & IB \\
\hline IM76-228(3) & RB867515(1) & $\mathrm{HB}$ & $\mathrm{F} 160^{(6)}$ & MEX68-200(6) & IB \\
\hline RB01640(1) & IN84-58(2) & $\mathrm{HB}$ & MEX68-200(6) & $\mathrm{F} 150^{(6)}$ & IB \\
\hline RB036066 $(1)$ & $?^{(2)}$ & $\mathrm{HB}$ & MEX68-200(6) & RB04823(1) & IB \\
\hline RB04813(1) & US85-1008(4) & $\mathrm{HB}$ & MEX68-200(6) & RB93509(1) & IB \\
\hline RB83102(1) & IM76-229(3) & $\mathrm{HB}$ & RB01623(1) & MEX68-200(6) & IB \\
\hline RB867515(1) & B70710(4) & $\mathrm{HB}$ & RB93509(1) & $\operatorname{Co} 421^{(5)}$ & IB \\
\hline RB92579(1) & IM76-228(3) & $\mathrm{HB}$ & RB93509(1) & MEX68-200(6) & IB \\
\hline RB92579(1) & IM76-229(3) & $\mathrm{HB}$ & US74-103(5) & RB92579(1) & IB \\
\hline
\end{tabular}

*Family ideotypes based on genealogical information; CO: conventional sugarcane family; HB: high biomass energy cane family; IB: intermediate biomass energy cane family - (2nd and $3^{\text {rd }}$ generation of S. spontaneum). (1) Sugarcane hybrid (Saccharum spp.), (2) S. spontaneum, (3) S. robustum, (4) $1^{\text {st }}$ generation of S. spontaneum, (5) $2^{\text {nd }}$ generation of S. spontaneum, (6) $3^{\text {rd }}$ generation of $S$. spontaneum; ? Unknown parent (multiparent cross). 
spaced $0.50 \mathrm{~m}$ apart, distributed in two 5-m long rows, spaced $1.40 \mathrm{~m}$ apart, with a total of 3.000 seedlings. In the T1 phase, the 30 families were classified according to the genealogy of their parents (family type), as follows: five conventional sugarcane (CO) families, derived from crosses between conventional sugarcane clones and varieties; 13 energy cane families with high biomass (HB) from crosses between clones of the species $S$. spontaneum and $S$. robustum with sugarcane hybrids; and 12 energy cane families with intermediate biomass (IB), from crosses of second and third generation $S$. spontaneum clones with sugarcane hybrids (Table 1).

Cane plant cutting occurred in December 2013. Disease incidence was evaluated in the ratoon crop in November 2014, 11 months after the first cut, in a favorable period for the occurrence of diseases of major importance for the crop.

\section{Second selection phase (T2)}

The second selection phase (T2) was installed in December 2014, with 27 families and 88 genotypes disease-free in $\mathrm{T} 1$, in which 7 were $\mathrm{CO}, 60 \mathrm{HB}$, and $21 \mathrm{IB}$, according to Table 1. Planting of T2 occurred in December 2014, at the Experimental Station Paranavaí, of the Federal University of Paraná, in Paranavaí, Paraná. This phase was arranged in an incomplete block design, with five blocks, i.e., four with 20 and one with only eight plots. Each experimental plot consisted of two 5-m rows, spaced 1,40 m apart, in which 18 buds per meter were planted. Disease occurrence was assessed in December 2015, in the cane plant cycle, 12 months after planting.

\section{Disease assessment}

\section{Brown rust}

For the evaluation of brown rust, the +3 leaves of all tillers of a plot were observed in both experimental stages, although in the first selection cycle (T1), the scores were assigned according to the mean plot performance (composed of a full sib family). The 1 - 9 diagrammatic scale score system was modified to a 4-grade scale, to assess the percentage of disease-affected leaf area (Purdy \& Dean, 1981; Amorim et al. 1987) (Table 2).

\section{Smut (Ustilago scitaminea)}

The clones' smut incidence was only evaluated in the $\mathrm{T} 1$ phase, whereas smut incidence on the ratoon tillers was evaluated in all families in both phases (T1 and T2). In T1, smut incidence was determined as the ratio between the number of clones (clumps) with at least one whip and the total number of clones per family. The ratio of the total number of ratoon tillers by the number of ratoon tillers with whips per plot was determined to determine smut incidence on the ratoon tillers. The total frequencies of smut incidence on clones and smut incidence on the ratoon tillers in each family type were determined. In T2, only the clones smut incidence of each family with or without symptoms were considered.

Table 2. Brown rust severity scales proposed by Amorim et al. (1987) and modified scaled.

\begin{tabular}{|c|c|c|c|c|}
\hline \multicolumn{3}{|c|}{ Amorim et al. (1987) } & \multicolumn{2}{|r|}{ Modified Scale } \\
\hline Score & LAS $(\%)^{*}$ & LBRR & Score & LBRR \\
\hline 1 & 0 & Highly Resistant & 1 & Highly Resistant (HR) \\
\hline 2 & 0.5 & Resistant & 2 & Resistant (R) \\
\hline 3 & 1 & Resistant & 2 & Resistant (R) \\
\hline 4 & 5 & Moderately Resistant & & \\
\hline 5 & 10 & Moderately Susecptible & 3 & Moderately Susceptible (MS) \\
\hline 6 & 25 & Susceptible & & \\
\hline 7 & 35 & Susceptible & & \\
\hline 8 & 50 & Susceptible & 4 & Susceptible (S) \\
\hline 9 & $>50$ & Highly Susceptible & 4 & Susceptivie (S) \\
\hline
\end{tabular}

*percentage of leaf area with symptoms (LAS (\%)) proposed by Purdy \& Dean (1981); levels of brown rust reaction (LBRR) associated with different score scales. 


\section{Results and discussion}

Brown rust and smut are diseases that cause losses in sugarcane yield worldwide. Genetic resistance is the most commonly used control method in disease management. Therefore, studies that evaluate new families and clones of high biomass disease reaction should be further explored within genetic breeding programs. The higher resistance to diseases in sugarcane crosses is due to the knowledge and mastery of breeding for the development of varieties, especially regarding the parents' response to the diseases. We evaluated progenies from 30 crosses in 2 selection phases, involving elite cultivars (Saccharum spp.), S. spontaneum, and $S$. robustum from different generations and named three family type according to the species involved in the crosses: conventional (CO), intermediate biomass (IB) and high biomass (HB).

\section{Family performance in the first selection phase (T1)}

According to the scores of brown rust severity in the family plots in the first selection phase (T1), the rust reactions levels of the HB families RB93509 × Co285, RB867515 × B70710, RB83102 $\times$ IM76-229, IM76-228 × RB867515, and F150 × IN84-88, which represented $38 \%$ of the evaluated families, were moderately susceptible (MS) and susceptible (S) (Figure 1A). Approximately 15\% of the HB families (SP81-3250 $\times$ US85-1008 and RB01640 $\times$ IN84-58) were classified as highly resistant (HR) in all plots (Figure 1A).

Of the intermediate biomass families (IB), $16 \%$ (MEX68-200 $\times$ F150 and Co617 $\times$ POJ2878) reacted MS and $S$ to brown rust (Figure 1A). The only IB family with resistance score HR in all plots was MEX68-200 × RB04823. Conversely, the plots of all five $\mathrm{CO}$ families, with the exception of RB867515 $\times$ RB965518, were classified as HR (Figure 1A).

Considering the overall performance of the family types in the evaluations of $\mathrm{T} 1$, the $\mathrm{HB}$ and IB families were evaluated with the highest brown rust susceptibility scores ( 3 and 4 ) on more than half the plots, i.e., classified as MS and S (Figure 1B). Of the plots with CO families, $88 \%$ were classified as highly resistant (Figure 1B).

The parents should be characterized for disease susceptibility to promote crosses between resistant parents, and consequently breed progenies with a higher frequency of resistant plants (Croft et al. 2008), to avoid obtaining progenies with susceptibility, mainly to brown rust. In Brazil, high biomass sugarcane clones have been developed in the Northeastern region, where rust and smut problems are smaller, despite recent reports of the occurrence of these diseases.

In the first selection phase, the rust frequency was higher (MS and S) in the families' plots denominated as HB and IB, and smut incidence was higher in the ratoon tillers and clones. In T1, 88 clones were selected without smut and brown rust symptoms and with greater vigor.

The unmeasured characteristics coupled with the fact that field breeders are familiar with the selection of conventional clones resulted in a higher rigor in the selection of this type of family and, consequently, in a lower number of conventional clones (CO) selected for $\mathrm{T} 2$, in spite of the low incidence of smut and rust in the families evaluated in T1.

The high biomass (HB) families based on crosses between hybrid sugarcane (Saccharum spp.), $S$. robustum, and $S$. spontaneum (until the third generation) had similar smut incidence percentages to those of the other family types. However, the incidence of clones with brown rust symptoms was at least $19 \%$ higher than that of the other family types, which resulted in a lower number of clones without symptoms of either disease in $\mathrm{T} 2$.

$S$. spontaneum and $S$. robustum genes' introgression are the main source of resistance to the major sugarcane diseases (Matsuoka et al. 2014). In contrast, we observed a higher brown rust and smut incidence in crosses of sugarcane hybrids with $S$. spontaneum and $S$. robustum in $\mathrm{T} 1$ than of the progenies derived from crosses among commercial hybrids.

The divergence from the results reported in the literature allows the conclusion that this type of cross will not always favor progenies with a high frequency of smut and brown rust resistant clones. Some symptom-free clones for the diseases studied in $\mathrm{T} 1$ presented symptoms in all three types of families in T2. The appearance of symptoms on clones previously selected as resistant is common in breeding programs.

Over a period of five years, 15 genotypes apparently resistant to brown rust were discarded from the breeding program conducted at Canal 


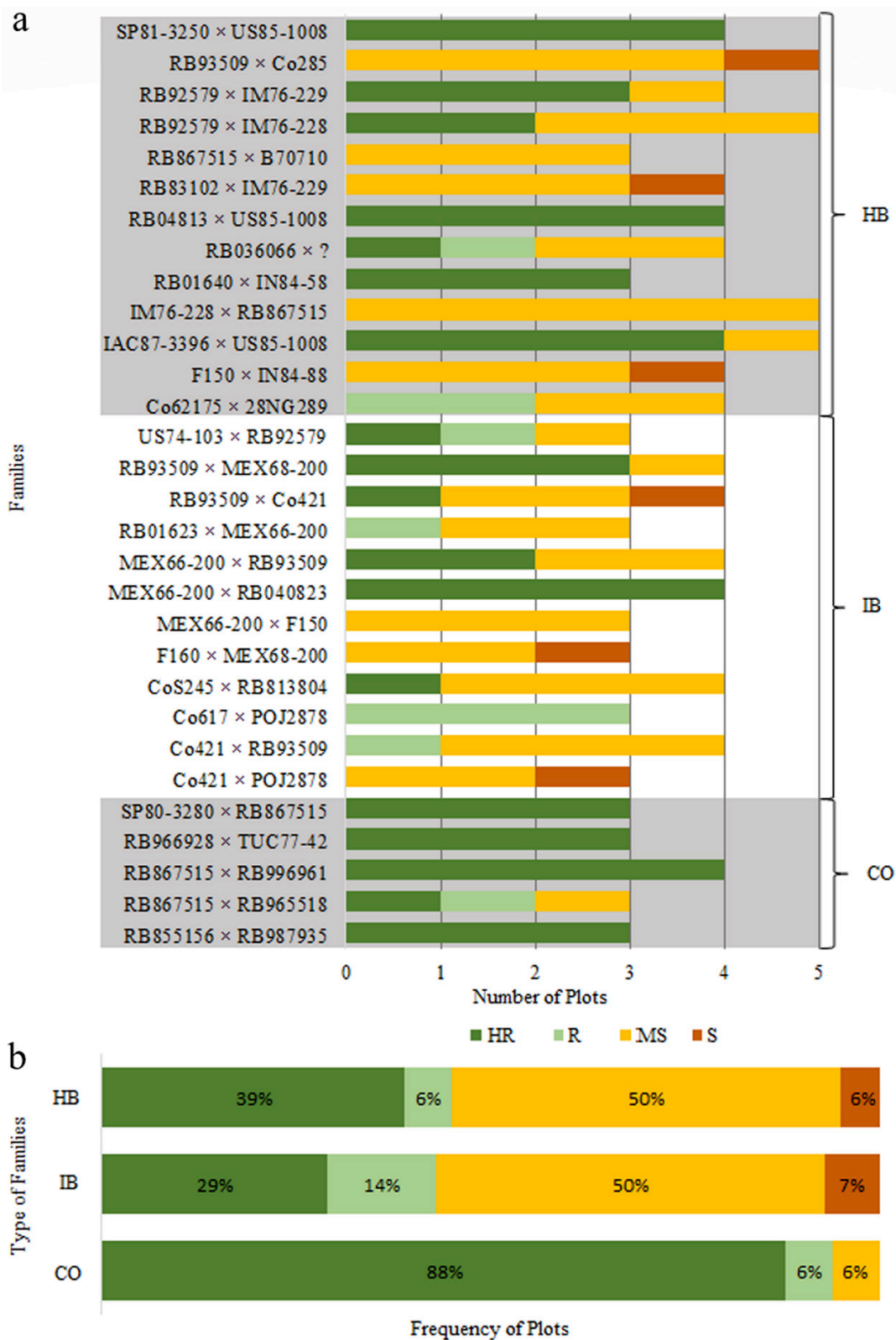

Figure 1. Reaction levels to brown rust (Puccinia melanocephala) on plots of conventional (CO), intermediate (IB) and high biomass (HB) sugarcane in the first selection phase (A) and the respective percentages of each family type (B). HR = Highly resistant, $\mathrm{R}=$ Resistant, MS = Moderately susceptible and $\mathrm{S}=$ Susceptible.

Point - Florida, about one year prior to release after the appearance of disease symptoms (Glynn et al., 2013). In 2007, L79-1002, a variety with high biomass yield, was released in the United States, with CP52-68 as female and Tainan, an $S$. spontaneum clone, as the male parent. After the expansion of the cultivation area of L79-1002 to the states of Louisiana and Florida, smut susceptibility was stated (Bischoff et al. 2008).

The non-appearance of symptoms on susceptible clones may be related to differences between experimental field conditions. In other words, the clones are exposed to unequal inoculum levels. Artificial inoculation would be an interesting tool 
to be used for providing a more uniform exposure of the clones (Sood et al., 2009). The clone selection efficiency could also be improved using molecular tools to study genes related to brown rust and smut resistance in sugarcane (Li et al., 2018).

Smut incidence on all HB families varied from 1 to $32 \%$ of the clones evaluated in the crosses (Figure 2A), with a mean of $16.69 \%$ of smut-infected clones (Figure 2B), i.e., smut incidence was highest on this family ideotype. In this family's ideotype, the smut incidence on clones was $<10 \%$ only for the crosses SP81-3250 $\times$ US85-1008, RB867515 $\times$ B70710, and IAC87-3396 $\times$ US85-1008 (Figure 2A).

The smut incidence on clones on the crosses RB92579 × IM76-229, RB92579 × IM76-228, and RB01640 $\times$ IN84-58 exceeded $25 \%$ and was associated with the highest incidence of ratoon tillers (>15\%) (Figure 2A). In the HB families, smut incidence on the ratoon tillers ranged from 1 to $34 \%$ (Figure 2A), and smut symptoms were observed on an average $10 \%$ of the ratoons of this family type (Figure 2B).

Only two IB families (MEX68-200 $\times$ F150 and Co421 $\times$ POJ2878) were smut-free at the time of the evaluation, and 25\% (US74-103 × RB92579, RB01623 × MEX68-200, CoS245 × RB813804, and Co421 $\times$ RB93509) had a smut incidence on clones of $10 \%$. However, none of the IB families' incidence levels exceeded the mean percentage of $17 \%$, as observed in HB families (Figure 2A and $2 \mathrm{~B}$ ). The families with smut-free progenies were RB867515 × RB965518 (CO), RB966928 $\times$ TUC77-42 (CO), Co421 × POJ2878 (IB), and MEX68-200 $\times$ F150 (IB) (Figure 2A, of which the latter two were graded with scores of $>3$ for brown rust in all plots (Figure 1A).

a

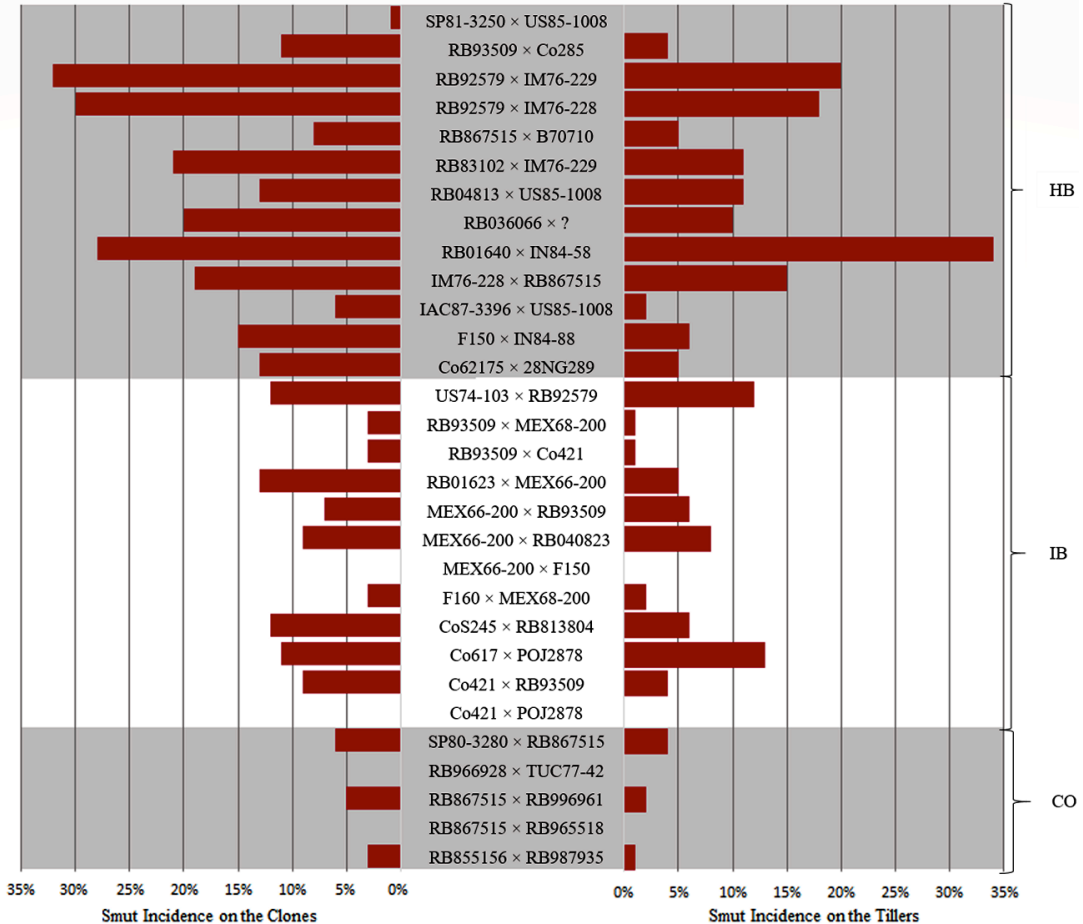

b

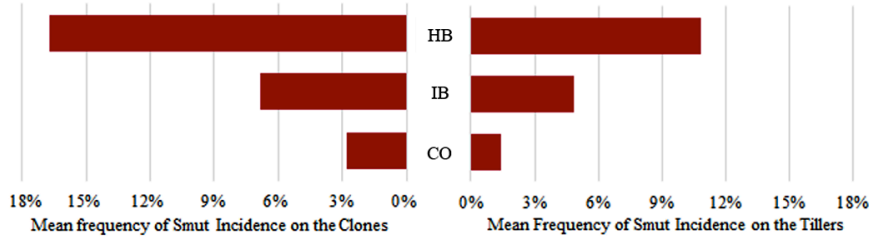

Figure 2. Incidence of clones and tillers with smut (Sporisorium scitamineum) in families (A) and family types (B) conventional (CO), intermediate biomass (IB) and high biomass (HB), in the first selection phase (T1). 
Of the three $\mathrm{CO}$ families with smut symptoms, the highest smut incidence on clones of $6 \%$ was observed on cross SP80-3280 × RB867515. This percentage is lower than the overall mean of the IB families (Figure 2A). Concerning the CO families, the progenies of two families (RB966928 $\times$ TUC77-42 and RB867515 × RB965518) were smut symptom-free, and in terms of overall performance, had the lowest percentage $(<3 \%)$ of mean smut incidence on clones and ratoon tillers, considering all three evaluated family ideotypes (Figure 2A and 2B). Of the clones evaluated in T1, $88(\approx 4 \%$ of the total) were selected for $\mathrm{T} 2$, free of symptoms of the studied diseases, and good performance for relevant agronomic traits such as high vigor and tillering capacity.
Recurrent selection is an efficient method to increase the fiber content of $S$. spontaneum and $S$. robustum populations' fiber contents since high-fiber parents can generate clones superior to those of the currently cultivated varieties. This strategy can also contribute to the search for disease resistance sources, and that must be implemented in breeding programs for the development of high biomass clones and varieties (Matsuoka et al. 2014).

\section{Family performance in the second selection phase (T2)}

The results of the clone performance of the different family types evaluated in $\mathrm{T} 2$ are listed in Table 3. High resistance to brown rust and the

Table 3. Number and ideotype of clones per family at each Level of Brown Rust Reaction (LBRR) and Smut symptoms during the second selection phase (T2).

\begin{tabular}{|c|c|c|c|c|c|c|c|c|}
\hline \multirow{2}{*}{ TYPE$^{1}$} & \multirow{2}{*}{ Family } & \multicolumn{4}{|c|}{ LBRR } & \multicolumn{2}{|c|}{ SMUT } & \multirow{2}{*}{$\mathrm{HR} \cap \mathrm{A}^{2}$} \\
\hline & & HR & $\mathrm{R}$ & MS & $\mathrm{S}$ & A & $\mathrm{P}$ & \\
\hline $\mathrm{CO}$ & RB855156 × RB987935 & 1 & 0 & 0 & 0 & 0 & 1 & 0 \\
\hline $\mathrm{CO}$ & RB867515 × RB965518 & 0 & 0 & 1 & 0 & 1 & 0 & 0 \\
\hline $\mathrm{CO}$ & RB867515 × RB996961 & 2 & 0 & 0 & 0 & 1 & 1 & 1 \\
\hline $\mathrm{CO}$ & RB966928 × TUC77-42 & 1 & 0 & 0 & 0 & 1 & 0 & 1 \\
\hline $\mathrm{CO}$ & SP80-3280 × RB867515 & 2 & 0 & 0 & 0 & 2 & 0 & 2 \\
\hline IB & Co421 × RB93509 & 1 & 0 & 0 & 0 & 1 & 0 & 1 \\
\hline IB & Co617 × POJ 2878 & 4 & 1 & 1 & 1 & 5 & 2 & 4 \\
\hline IB & $\mathrm{CoS} 245 \times \mathrm{RB} 813804$ & 1 & 0 & 0 & 0 & 0 & 1 & 0 \\
\hline IB & F160 × MEX68-200 & 2 & 0 & 0 & 0 & 1 & 1 & 1 \\
\hline IB & MEX68-200 × RB04823 & 0 & 1 & 0 & 0 & 1 & 0 & 0 \\
\hline IB & MEX68-200 × RB93509 & 2 & 0 & 0 & 0 & 2 & 0 & 2 \\
\hline IB & RB01623 × MEX68-200 & 1 & 0 & 0 & 0 & 1 & 0 & 1 \\
\hline IB & RB93509 × Co421 & 4 & 0 & 0 & 0 & 3 & 1 & 3 \\
\hline IB & RB93509 × MEX68-200 & 1 & 0 & 0 & 0 & 1 & 0 & 1 \\
\hline IB & US74-103 × RB92579 & 1 & 0 & 0 & 0 & 1 & 0 & 1 \\
\hline HB & Co62175 × 28NG289 & 1 & 0 & 0 & 0 & 0 & 1 & 0 \\
\hline HB & F150 × IN84-88 & 2 & 0 & 0 & 0 & 1 & 1 & 1 \\
\hline HB & IAC87-3396 × US85-1008 & 4 & 0 & 0 & 0 & 2 & 2 & 2 \\
\hline HB & IM76-228 × RB867515 & 3 & 1 & 0 & 0 & 4 & 0 & 3 \\
\hline HB & $\mathrm{RB} 01640 \times \mathrm{IN} 84-58$ & 2 & 0 & 0 & 0 & 2 & 0 & 2 \\
\hline $\mathrm{HB}$ & RB036066 ×? & 4 & 3 & 2 & 2 & 7 & 4 & 1 \\
\hline $\mathrm{HB}$ & RB83102 × IM76-229 & 2 & 2 & 4 & 3 & 9 & 2 & 1 \\
\hline $\mathrm{HB}$ & RB867515 × B70710 & 3 & 0 & 0 & 1 & 3 & 1 & 3 \\
\hline HB & RB92579 × IM76-228 & 11 & 1 & 1 & 0 & 7 & 6 & 6 \\
\hline $\mathrm{HB}$ & RB92579 × IM76-229 & 2 & 0 & 0 & 1 & 3 & 0 & 2 \\
\hline $\mathrm{HB}$ & RB93509 × Co285 & 2 & 0 & 0 & 2 & 4 & 0 & 2 \\
\hline $\mathrm{HB}$ & SP81-3250 × US85-1008 & 1 & 0 & 0 & 0 & 0 & 1 & 0 \\
\hline \multicolumn{2}{|c|}{ TOTAL CO (\%) } & 86 & 0 & 14 & 0 & 71 & 29 & 57.14 \\
\hline \multicolumn{2}{|c|}{ TOTAL IB (\%) } & 80.95 & 9.52 & 4.76 & 4.76 & 76.19 & 23.81 & 66.67 \\
\hline \multicolumn{2}{|c|}{ TOTAL HB (\%) } & 61.67 & 11.67 & 11.67 & 15 & 70 & 30 & 38.33 \\
\hline
\end{tabular}

${ }^{1} \mathrm{CO}$ : conventional sugarcane family; IB: intermediate biomass family; HB: high biomass family. LBRR: HR: highly resistant, R: resistant, MS: moderately susceptible and S: susceptible and absence $(\mathrm{A})$ or presence $(\mathrm{P})$ of symptoms during the second selection phase (T2). ${ }^{2} \mathrm{HR} \cap \mathrm{A}$ : number of clones per family with high rust resistance and absence of smut symptoms 
absence of smut symptoms are indispensable characteristics (HRกA) for selecting clones that constitute the next selection phase since susceptibility to any disease would impair the release of a new variety (Table 3 ). In T2, 41 clones had no brown rust symptoms (i.e., 4 conventional sugarcane, 14 intermediate biomass, and 23 high biomass energy cane clones).

Of all five $\mathrm{CO}$ families evaluated in $\mathrm{T} 1$, at least one clone was selected for the second selection phase, with a total of seven clones. Five CO clones (57.14\%) were symptom-free for both studied diseases (Table 3). Six CO clones (86\%) were classified as highly resistant (HR), and only one clone of the family RB867515 × RB996961 was classified as HR and free of smut symptoms (A) (Table 3), when evaluated in T1, this CO family, had no smut symptoms but was the only one of those selected for smut-symptom absence with plots that were not classified as HR for brown rust (Figures 1A and 2A).

Among the 12 IB families evaluated in T1, two families (MEX68-200 $\times$ F150 and Co421 $\times$ POJ2878) had no clones selected for the T2 phase (Table 3). The MS and S notes for brown rust influenced these 2 families' exclusion during breeding phases, although not smut incidence was observed in the $\mathrm{T} 1$ selection phase (Figure 2A and $3 \mathrm{~A})$. In the IB families, 14 clones were identified as HRกA in stage T2 (Table 3). From the cross for IB, Co421 × RB93509 and the reciprocal, RB93509 $\times$ Co421, five HR clones were derived, of which only one had brown rust symptoms.

The HB families with the highest number of clones selected for T2 were: RB036066 $\times$ ?, RB83102 × IM76-229, and RB92579 × IM76-228, with at least 11 clones selected in T1, although only the family RB92579 $\times$ IM76-228 generated more than one clone without symptoms of either disease (Table 3). The overall frequencies of HR against brown rust in $\mathrm{T} 2$ in the selected $\mathrm{CO}(86 \%)$ and IB families $(80.95 \%)$ were higher than the frequencies for the absence of smut symptoms (A) of 71 and $76 \%$, respectively (Table 3 ). The families selected for HB had a higher overall frequency of clones with no smut symptoms (70\%) than the clones evaluated as highly brown rust-resistant (61.67\%) (Table 3).

Considering the overall performance of clones

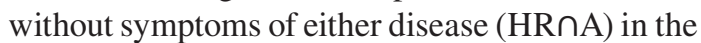
evaluated family types, which may be selected in $\mathrm{T} 2$, in the families selected for HB (37.33\%), the percentage obtained was at least $28 \%$ lower than that of the selected CO (57.14\%) and IB families $(66.67 \%)$ (Table 3). Of the 88 clones evaluated in $\mathrm{T} 2,41$ clones $(\approx 46 \%)$ were free of brown rust and smut symptoms (Table 3 ).

For the achievement of energy cane varieties, more studies on the parents that can contribute to increasing the fiber content are needed, particularly $S$. spontaneum and $S$. robustum accessions, to better understand the general and specific combining abilities for the traits biomass production as well as disease susceptibility.

Therefore, the introduction of new accessions and recurrent selection within $S$. spontaneum and $S$. robustum populations is now necessary to broaden the genetic base of the germplasm banks (BAG) of RIDESA and, thus, to be able to exploit the variability that can be generated from there, to raise the fiber content and resistance to the major crop diseases of the new populations.

These strategies should be adopted because, while conventional breeding has generated new combinations, testing and selecting the new clones in the field under the selection pressure caused by newly arisen pathogen strains, the $S$. spontaneum and $S$. robustum accessions maintained by the RIDESA BAG were not subjected to the same selection pressure. This may explain the fact that the HB crosses evaluated in this study were not efficient in the generation of brown rust and smut resistant clones.

Considering the evaluation in other stages of the breeding program, the clones used in this study that are disease-free and high-performing for the yield variables will become candidates to be released as new varieties and/or will be maintained in a germplasm bank as parents for the development of conventional and intermediate and high biomass sugarcane varieties.

\section{Conclusion}

Higher brown smut and rust rates were observed in intermediate and high biomass sugarcane families in the first selection phase. In the second selection phase, the brown rust incidence of high biomass families was higher. However, at the end of two selection phases, intermediate and high biomass sugarcane clones without disease symptoms were selected. 


\section{Literature Cited}

Amorim, L.; Bergamin, F.A.; Cardoso, C.; Moraes, V.A.; Fernandes, C.R.

1987. Metodologia de avaliação da ferrugem da canade-açúcar (Puccinia melanocephala). Boletim Técnico Copersucar, 39: 13-16.

Balsalobre, T.W.A.; Mancini, M.C.; Pereira, G.S.; Anoni, C.O.; Barreto, F.Z.; Hoffmann, H.P.; Souza, A.P.; Garcia, A.A.F.; Carneiro, M.S.

2016. Mixed modeling of yield components and brown rust resistance in sugarcane families. Agronomy Journal, 108: 1824-1837.

Barbosa, M.H.P.; Deon, M.V.; Bressiani, J.A.; Silveira, L.C.I.; Peternelli, L.A.

2005. Selection of sugarcane families and parents by REML/ BLUP. Crop Breeding Applied Biotechnology 5: 443-450.

Barbosa, M.H.P.; Resende, M.D.V.; Dias, L.A.S.; Barbosa,

G.V.S.; Oliveira, R.A.; Peternelli, L.A.; Daros, E.

2012. Genetic improvement of sugarcane for bioenergy: the Brazilian experience in network research with RIDESA. Crop Breeding and Applied Biotechnology, 12: 87-98.

Bergamin-Filho, A.L.; Cardoso, C.O.N.; Sanguino, A.; Irvine, J.E.; Silva, W.M.

1987. Carvão da cana-de-açúcar e sua epidemiologia. Boletim Técnico Copersucar, Edição especial: 1-23.

Bischoff, K.P.; Gravois, K.A.; Reagen, T.E.; Hoyc, J.W.; Kimbengd, C.A.; Labordea, C.M.; Hawkinsa, G.L. 2008. Registration of "L79-1002" sugarcane. Journal of Plant Registrations, 2: 211-217.

Brasileiro, B.P.; Mendes, T.O. de P.; Peternelli, L.A.; Silveira, L.C.I.; Resende, M.D.V.; Barbosa, M.H.P.

2016. Simulated individual best linear unbiased prediction versus mass selection in sugarcane families. Crop Science, 56: $570-575$.

Camochena, R.C.; Santos, I. dos; Manteli, C.; Malagi, G.;

Mazaro, .S.M.; Dallemole-Giaretta, R.

2012. Reação de genótipos de milho à mancha ocular causada por Kabatiella zeae. Semina: Ciências Agrárias, 33: 1315-1322.

Croft, B.J.; Magarey, R.C.; Allsopp, P.G.; Cox, M.C.; Wyllcox,

T.G.; Milford, B.J.; Wallis, E.S.

2008. Sugarcane smut in Queensland: arrival and emergency response. Australian Plant Phatology, 37: 26-34

Dos Santos, H.G. Jacomine, P.K.T.; Anjos, L.H.C.; Oliveira,

V.A.; Oliveira, J.B.; Coelho, M.R.; Lumbreras, J.F.; Cunha, T.J.F. 2018. Sistema Brasileiro de Classificação de Solos. Embrapa. Brasília, DF. Brazil.

Glynn, N.C. Laborde, C.; Davidson, R.W.; Irey, M.S.; Glas, B.; D'Hont, A.; Comstock, J.C.

2013. Utilization of a major brown rust resistance gene in sugarcane breeding. Molecular Breeding. 33: 323-331.

Ido, O.T.; Neto Lima, V. da C.; Daros, E.; Possamai, J.C.; Zambon, J.L.C.; Weber, H.; Oliveira, R.A.

2006. Incidência e severidade da ferrugem em clones de cana-de-açúcar no estado do Paraná. Pesquisa Agropecuária Tropical, 36: 159-163.
Li, Z.; Su, Y-C.; Yu, Q.; Chen, Y.; Gao, S-W.; Zhang, Y-G.; Que, Y-X.; Xu, L-P.

2018. Molecular insights into brown rust resistance and potential epidemic based on the Brul gene in sugarcane varieties and new elite clones. Euphytica, 214: 189.

Matsuoka, S.

1993. Análise retrospectiva de perdas causadas pela ferrugem da cana-de-açúcar em São Paulo. In: $5^{\circ}$ Congresso Nacional da STAB, Águas de São Pedro. Anais, STAB. Piracicaba, Brazil. pp. 148-156.

Matsuoka, S. Kennedy, A.J., Santos, E.G.D.; Tomazela, A.L.; Rubio, L.C.S.

2014. Energy Cane: Its concept, development, characteristics and prospects. Advances in Botany, 2014: 1-13. DOI: $10.1155 / 2014 / 597275$

Purdy, L.H.; DEAN, J.L.

1981. A system for recording data about the sugarcane rust/ host interactions. Sugarcane Pathologist's Newsletter, 27(1): 35-40.

Rago, A.M.; Casagrande, M.V.; Massola Junior, N.S. 2009.Variabilidade patogênica de Ustilago scitaminea no Estado de São Paulo. Summa Phytopathologica, 35: 93-97.

Ramdoyal, K.; Sullivan, S.A.S.; Lim, S.C.L.C.Y.; Badaloo,

G.H., Saumtally, S.; Domaingue, R.

2000. The genetics of rust resistance in sugar cane seedling populations. Theoretical and Applied Genetics, 100: 557-563.

Ramos, R.S.; Brasileiro, B.P.; Silveira, L.C.I.; Kist, V.;

Peternelli, L.A.; Barbosa, M.H.P.

2007. Selection of parents, families and clones to obtain energy cane. Agronomy Journal, 109: 1-7.

Silveira, L.C.I.; Brasileiro, B.P.; Kist, V.; Daros, E.

2015a. Genetic diversity and coefficient of kinship among potential genitors for obtaining cultivars of energy cane. Revista Ciência Agronômica, 46: 358-368.

Silveira, L.C.I.; Brasileiro, B.P.; Kist, V.; Weber, H.; Daros,

E; Barbosa, M.H.P.

2015b. Selection strategy in families of energy cane based on biomass production and quality traits. Euphytica, 204: 443-455.

Silveira, L.C.I.; Brasileiro, B.P.; Kist, V.; Weber, H.; Daros,

E.; Peternelli, L.A.; Barbosa, M.H.P.

2016. Selection in energy cane families. Crop Breeding and Applied Biotechnology, 16: 298-306.

Simmonds, N.W.

1996. Family selection in plant breeding. Euphytica, 90: 201-208.

Sood, S.; Comstock, J.C; Glynn, N.C.

2009. Leaf whorl inoculation method for screening sugarcane rust resistance. Plant disease, 93: 1335-1340.

Tokeshi, H., Rago, A.

2005. Doenças da cana-de-açúcar. In: Kimati, H., Amorim, L., Rezende, J.A.M., Bergamin Filho, A., Camargo, L.E.A. (Ed.). Manual de Fitopatologia 2: Doenças das plantas cultivadas. Agronômica Ceres. São Paulo, Brazil. pp. 185-196. 
